\title{
Minimál invazivitás a kézsebészeti érzéstelenítésben
}

\author{
DR. SASVÁRI EDGÁR, DR. MILKOVICS RÓKUS, DR. GAÁL PÉTER, \\ DR. BALATINCZ PÉTER, DR. SOMORAI ISTVÁN
}

\section{ÖSSZEFOGLALÁS}

2013 óta egyre több közlés jelent meg az adrenalinnal kevert lidocainnal végzett helyi érzéstelenítés kézsebészeti felhasználásáról. A szer használata már kipróbált, plasztikai sebészetben, fogászatban gyakran használják az érszúkítővel kevert helyi érzéstelenítő oldatot. Mégis, a végtagsebészetben, kézsebészetben ennek felhasználása nem volt gyakori. Az elmúlt négy-öt évben külön irányzat alakult ki a kézsebészetben a lidocain-adrenalinnal helyi érzéstelenítésben végezhető mútétekkel kapcsolatban. Az irányzat angol mozaikszóval: WALANT módszer, azaz wide awake (éber állapotú beteg), local anaesthetic (helyi érzéstelenítésben végzett), no tourniquet (vértelenítő mandzsetta használata nélküli) eljárás. Találkozunk még a WAHS rövidítéssel (Wide Awake Hand Surgery). A közelmúltban több kongresszus anyagában találunk előadást erről az érzéstelenítési eljárásól és az eredményekről. Az eljárás és irányzat fő képviselője Donald Lalonde kanadai sebész, aki könyvet írt erről a módszerről és tapasztalatairól. A kézsebészeti mútétek jelentős része elvégezhető ezzel az eljárással anélkül, hogy a végtagot mandzsettával vértelenítenénk. Ezáltal általános, vagy regionális érzéstelenítési eljárások bizonyos mútéteknél mellőzhetővé válnak. A módszert osztályunkon 2014 októbere óta használjuk egyes kézsebészeti mútétek esetén. A közleményben az eljárás leírását, valamint egyéni tapasztalatainkat közöljük. Bizonyosak vagyunk abban, hogy a technikát Magyarországon már többen használják. Dolgozatunkat indokolja, hogy hasonló összefoglaló leírással a magyar szakirodalomban még nem találkoztunk.

\section{Kulcsszavak: $\quad$ Ambuláns eljárás; Anesztetikumok; Egynapos sebészet; Helyi érzéstelenítés; Kézsebészet;}

E. Sasvári, R. Milkovics, P. Gaál, P. Balatincz, I. Somorai: Minimally invasive method in hand surgery anesthesia

Since 2013, there has been an increasing number of reports on the use of local anesthesia with adrenaline mixed with lidocaine in hand surgery. The drug has already been tried, in plastic surgery and dentistry the local anesthetic solution mixed with vasoconstrictor is often used. However, its use was not common in limb surgery and hand surgery. In the last four to five years, there has been a distinct trend in the field of manual anesthesia with lidocaine-adrenaline in hand surgery. The trend with the English acronym: WALANT method, which is a wide awake local anesthetic no tourniquet procedure. We'll also meet with the WAHS abbreviation (Wide Awake Hand Surgery). Recently, several congressional papers contain lectures on this anesthetic and the results. The main representative of the procedure and trend is a Canadian surgeon, Donald Lalonde, who has written a book on this method and his experience. A significant amount of hand surgery can be done with this procedure without the need to cuff the limb. As a result, general or regional anesthesia procedures are avoided in certain surgeries. We have been using this method in our department since October 2014 for some hand surgery. In the communication, we provide a description of the procedure and our individual experiences. We are sure that the technique is already used more and more frequently in Hungary. The reasoning of our dissertation is that we have not encountered a similar summary in the Hungarian literature.

Keywords:

Ambulatory surgical procedures - Methods; Anesthesia, local - Methods; Anesthetics, local - Administration \& dosage; Hand - Surgery; 


\section{BEVEZETÉS}

\section{Elvi alapok}

A kézsebészeti mútétek elvégzésének alapvető feltételei vannak. Ilyenek a pontos diagnózis, mútéti terv, a technikai feltételek megléte, a gyakorlat a mútét elvégzésében, a sebészeti anatómia ismerete, megfelelő nagyítás használata, és nem utolsó sorban a jó látási viszonyok megléte, amely az operálandó terület vértelenítésével érhető el. Eddig, megfelelően vértelen mútéti területet kizárólag a különféle mandzsettás vértelenítési eljárásokkal tudtunk biztosítani, amelyek bár néhány percig tolerálhatóak, mégis, használatuk magával vonta az általános, vagy regionális érzéstelenítés szükségességét.

A WALANT módszer során megfelelő vértelenséget tudunk elérni a lidocainhoz kevert adrenalinnal. Az érzéstelenítés elérése mellett az operálandó terület vértelen lesz. A módszer bevezetéséhez szükség volt egy dogma felszámolására, amely a mai napig a gyógyszergyárak ismertetőjében szerepel, miszerint adrenalinnal kevert lidocain kézbe, kézujjakba nem adható be a várható keringészavar miatt. Az adrenalin használatának tiltása az 1920-1945 közötti időszak gyakorlata miatt alakult ki. Ekkor ugyanis 3,6 pH értékű procain-adrenalin oldatot használtak helyi érzéstelenítésre, amelyek $\mathrm{pH}$-ja hosszabb tárolás után akár 1-re is lecsökkent, azaz rendkívül savas kémhatású volt. Az ekkor leírt nekrózisok - 48 következményes ujjamputációról számoltak be - mégsem az adrenalin használata, hanem az oldat savas kémhatása miatt következtek be. 1948 után került bevezetésre a lidocain, de a tiltást megörökölte $(1,4,9)$.

\section{Milyen előnyei vannak az eljárásnak?}

\section{Páciensbarát eljárásról van szó}

A mútét előtti kivizsgálás, az ehhez szükséges többszöri kórházi megjelenés, szükségtelenné válik. Megelőző vizsgálatokat csak speciális esetekben kérünk. Nincs mútét előtti carentia, sőt a pácienseket bíztatjuk a reggeli szokásos étkezésre, gyógyszerek bevételére. Mútét előtt nem szükséges premedikáció, nincs infúzió, ágyhoz kötöttség, mütét körüli időszakban a páciens mozoghat, táplálkozhat, állapota végig teljesen éber.

\section{Intraoperativ mozgásvizsgálat lehetösége}

Pattanó ujj esetén régi alapelv, hogy az ínhüvely bemetszés után, mútét alatt a páciens aktív mozgását vizsgálni kell. Ugyanígy ínátültetések, ínvarratok, korrekciós osteotomiák vagy arthrodesisek esetén is fontos lehet az aktív mozgás vizsgálata, amely kizárólag éber betegen lehetséges.

\section{Praktikus elönyök}

Kiesik az általános, vagy regionális érzéstelenítés ideje, az altatási-ébredési periódus, vagy a plexus érzéstelenítésekre fordítandó idő, megfelelő szervezéssel mútéti sorozatok végezhetők, amelyek jelentősen javítják a mútő kihasználtságát.

$\mathrm{Az}$ érzéstelenítéshez nem szükséges az aneszteziológus orvos és asszisztens munkája. Nincs premedikáció (kizárólag nagyon nyugtalan pácienseknél adunk mútét előtti nyugtatót). Infúziót általában nem használunk. Az altatás körüli megszokott gyógyszerelés nem szükséges. A használt injekció ára alacsony. Így jelentős költségmegtakarítás jelentkezik ezeknél a mútéteknél.

\section{MÓDSZER}

Az eljárás lényege, hogy a helyi érzéstelenítőhöz kevert adrenalin az infiltrált területen lokális érszúkületet hoz létre. Ennek két hasznos effektusa van. Egyfelől az operálandó terület vértelensége érhető el, másfelől a helyi érzéstelenítőt a vasoconstrictor helyben tartja, így a felszívódásból adódó esetleges szisztémás mellékhatásokat csökkenti (szinonimák: tumescent local anaesthesia, extravascularis Bier block, WALANT). Az amid vagy észter típusú helyi érzéstelenítő szerek helyi diffúzió útján blokkolják az idegvégződések nátrium csatornáit, ezáltal megakadályozzák az akciós potenciál kialakulását, így a fájdalominger kialakulását. 


\section{A LIDOCAIN-ADRENALIN BIZTONSÁGA, MELLÉKHATÁSAI, KEZELÉSE}

\section{Lidocain allergia}

A valódi lidocain allergia igen ritka. Gyakran a lidocain injekcióhoz adott tartósító (metilparabén) okozza. Gyakori a korábban, például fogorvosnál kapott érzéstelenítésről szóló úgynevezett rosszullétek, szívdobogásérzés stb., amelyek nem nevezhetőek valódi allergiának. Lidocain allergia gyanúja esetén elvégezhető a bőrpróba, vagy lidocain helyett választhatunk észter típusú érzéstelenítőszert.

\section{Szisztémás lidocain mellékhatás}

Többségük vétlen intravascularis beadást követően jelentkezik, vagy dózistúllépés következménye. A vétlen intravascularis beadás nagyobb adagban konvulzív rohamot válthat ki. Ez közvetlenül a beadás után jelentkezik. Dózistúllépés miatti szisztémás reakció kifejlódéséhez idő kell, általában a beadást követő 20 perccel jelentkezik. Tünetei: fejfájás, fülzúgás, nyelv- és szájzsibbadás, az arcizomzat rángásai, bradycardia.

\section{Lidocain mellékhatások elkerülése}

Legfontosabb a dózistúllépés elkerülése. A lehető legkisebb, még effektív dózist használjuk. Maximális dózis lidocain esetén felnőtteknél $4 \mathrm{mg}$, lidocain/adrenalin esetén $7 \mathrm{mg}$ testsúly kilogrammonként. Az egyszerre beadott lidocain mennyisége testsúlykilogrammtól függetlenül ne lépje át az $500 \mathrm{mg}$ ot. Szükség lehet az érzéstelenített terület mérete miatt nagyobb térfogat beadására, ezt feles-negyedes hígításokkal érjük el (8). Kerülni kell a vétlen intravascularis beadást (elvégzendő minden esetben az aspirációs próba az injekciós beszúrás során). A szisztémás reakciókat lényegesen csökkenti a lidocainhoz adott vasoconstrictor. A beadás során fellépő érszűkület miatt a szisztémás keringésbe kerülő anyag mennyisége csökken. Konvulzióra hajlamos betegek esetében Diazepam adható mútét előtt 60 perccel. Az eredeti Lalonde-féle leírásban $1 \%$ lidocain/1/100000 adrenalin oldat használata szerepel. Magyarországon csak $2 \%$ lidocain/1/100000 adrenalin oldat kapható, így az eredeti leírásban szereplő értékeket át kell számolnunk (I. táblázat). Nagy területú infiltráció esetén az oldatot hígítjuk, a hígítás során az Adrenalin érszúkítő hatása még 4x-es hígításban sem csökken észlelhetően.

I. táblázat Lidocain-adrenalin injekció biztonságos dózisai (7mg/tskg), 0,5\%, 1\%, 2\%-os oldat esetén testsúlyra számolva

\begin{tabular}{|c|c|c|c|c|c|c|}
\hline Testsúly & 30 & 40 & 50 & 60 & 70 & 80 \\
\hline $\begin{array}{c}\text { Lidocain } \\
\mathrm{mg}\end{array}$ & 210 & 280 & 350 & 420 & 490 & 490 \\
\hline $0,5 \%$ & $42 \mathrm{ml}$ & $56 \mathrm{ml}$ & $70 \mathrm{ml}$ & $84 \mathrm{ml}$ & $96 \mathrm{ml}$ & $96 \mathrm{ml}$ \\
\hline $1,0 \%$ & $21 \mathrm{ml}$ & $28 \mathrm{ml}$ & $35 \mathrm{ml}$ & $42 \mathrm{ml}$ & $48 \mathrm{ml}$ & $48 \mathrm{ml}$ \\
\hline $2,0 \%$ & $10,5 \mathrm{ml}$ & $14 \mathrm{ml}$ & $17,5 \mathrm{ml}$ & $21 \mathrm{ml}$ & $24 \mathrm{ml}$ & $24 \mathrm{ml}$ \\
\hline
\end{tabular}




\section{Az adrenalin mellékhatásai}

A korábban leírt perifériás keringéskárosítás, ujjelhalások a beadott oldatok alacsony pH értékének következményei voltak. Azóta bizonyossá vált (több ezer mútétről szóló leírások alapján), hogy a fiziológiáshoz közeli pH érték esetén közvetlen szövetkárosítás, necrosis nem alakul ki adrenalin adása miatt. Chowdhry 1111 eset feldolgozása után egyetlen alkalommal sem észlelt keringészavart az injekció beadását követően (1). Korai nem kívánt mellékhatása lehet az adrenalinnak a palpitáció érzése, nyugtalanság, ezek a beadást követően gyorsan jelentkeznek. Kollapszus előfordulhat, ez fektetésre, Trendelenburg helyzetre spontán rendeződik. Későbbi mellékhatás lehet a beadás után tremor jelentkezése, ez általában 20-30 percen belül beavatkozás nélkül rendeződik. Fontos a beadott injekció pH értéke. Minél közelebb kerülünk a fiziológiás $\mathrm{pH}$ értékhez, annál kevésbé szövetkárosító és keringéskárosító a tevékenységünk. $A$ jelenleg használt $2 \%$-os lidocain/1/100000 adrenalin injekció $\mathrm{pH}$ értéke 4,2. Ez 1000 × savasabb, mint a szövetnedv pHja.

A kívánt $\mathrm{pH}$ beállítható $1 / 10$-nyi $8,4 \%$-os nátrium-bikarbonát oldattal. $\mathrm{Ha} 9 \mathrm{ml}$ 2\%-os lidocain/adrenalinhoz $1 \mathrm{ml}$ 8,4\%-os nátriumbikarbonátot adunk az oldat $\mathrm{pH}$ értéke 7,4 lesz, amely fiziológiás. A pufferelt oldat egyéb előnye: az érzéstelenítés során a kevésbé savas pH-jú oldat a lokális fájdalmat csökkenti. 7,4-es $\mathrm{pH}-\mathrm{n}$ a lidocain molekulák nagyobb hányada marad anionizált így stabilabb állapotban, ezzel az érzéstelenség időtartama növekszik. $\mathrm{Az}$ oldat $\mathrm{pH}$ javítása (pufferelése) elvégezhető a $9 \mathrm{ml}$ érzéstelenítőhöz felszívott $1 \mathrm{ml}$ 8,4\%-os nátrium-bikarbonáttal, vagy keverőtálban öszszekeverve és felszívva.

\section{AZ INJEKCIÓZÁS TECHNIKÁJA, LALONDE SZABÁLYAI}

A WALANT érzéstelenítés kivitelezéséhez pontos leírást adott Lalonde, az eljárás kidolgozója. A leírás minden apró részletre kiterjed, alapos. A WALANT érzéstelenítés technikáját tanulni kell, lényeges az apró részletek betartása.

\section{Lalonde elvek $(6,7,10)$}

1. Az előkészítés: Lalonde az érzéstelenítő oldatot testhőmérsékletre melegíti, majd pufferolja $1 \mathrm{ml}$ 8,4\%-os nátrium-bikarbonát oldattal. A hőmérséklet emelése és a pH fiziológiásra való beállítása csökkenti a beszúrási fájdalmat, a várható szövetkárosítást. Növeli az érzéstelenség időtartamát. Javasolja a "gate mechanizmusok" bekapcsolása miatt a beszúrás helyének egyéb mechanikus (feszítés, csípés, megemelés) vagy termikus (jég) ingerlését, ezzel csökkentve a primer beszúrás okozta fájdalominger mértékét.

2. A beszúráshoz nagyon vékony tút használ: 25-27 gauge az előírt tűvastagság. Mi a 25 gauge-os (narancssárga) tűt használjuk.

3. Az első beszúrás a megadott helyen a bőrfelületre merőlegesen történik. A ferde beszúrás több corpusculumot károsít, jobban fáj.

4. A beszúráskor a tút stabilizálja (kétkezes beszúrás), ezzel az akaratlan mozgások és felesleges fájdalom elkerülhető.

5. Az első beszúrás során $0,2-0,5 \mathrm{ml}$-es quadlit képez. A további infiltráció előtt körülbelül 45 másodperces szünetet tart, a pácienssel való megbeszélés alapján csak akkor halad tovább, ha a kezdeti beszúrás fájdalma megszúnt.

6. Az injekciós tű továbbtolása és az infiltráció alapvető módja a lassú fokozatos továbbhaladás. A kezdeti beszúrás után további $2 \mathrm{ml}$ oldatot - még merőleges tűvel - adunk be, ezt követően fordulunk párhuzamosan az érzéstelenítendő terület subdermalis régiójának infiltrációjára. A paralel érzéstelenítés (1-2. ábrák) centiméterenkénti előrehaladással történik úgy, hogy végig tapintjuk a tű hegyét, valamint a szúrás helyén kialakuló duzzanatot. Minden továbbhaladás előtt várakozunk néhány másodpercet.

7. A megfelelő érzéstelenítést jelzi a „blanching” effektus: azaz, az érzéstelenített terület elsápad a beadott adrenalin miatt (3. ábra).

8. Cél, hogy a tervezett beavatkozás minden tevékenységén kívül $1 \mathrm{~cm}$-es biztonsági zónát érzéstelenítsünk.

9. Nagyobb terület érzéstelenítése után újabb beszúrást csak már érzéstelenített területen végezzünk.

10. Az érzéstelenítés során elengedhetetlen a pácienssel való állandó verbális kontaktus, 
nyugtatás, kérdezés a fájdalomérzésről, ez is csökkenti a fájdalmat, és segít az érzéstelenítés tanulásában. Cél, hogy az első beszúrás rövid éles fájdalmán kívül egyéb fájdalom az érzéstelenítés során ne jelentkezzen.

11. Az érzéstelenítés kivitelezése időigényes. Jól begyakorolt technika mellett is néhány percet igénybe vesz. Mútéti statisztikák alapján a kellő érzéstelenség és vértelenség beállásának ideje átlagosan 20-30 perc. Mi az érzéstelenítés után 30 perccel visszük mútőbe a beteget az előkészítőből, ennyi idő elégséges az érzéstelenség és vértelenség eléréséhez.

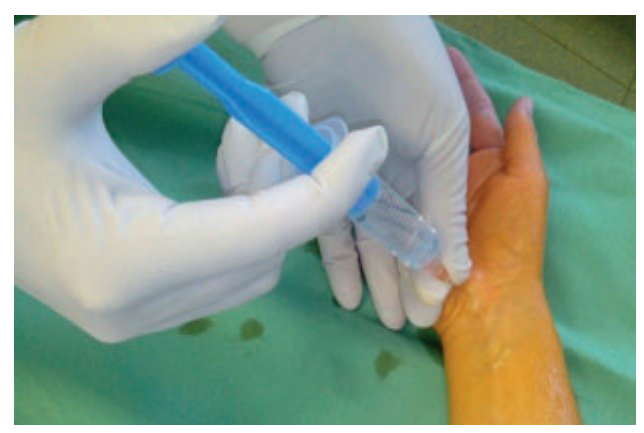

1. ábra

Merőleges beszúrás

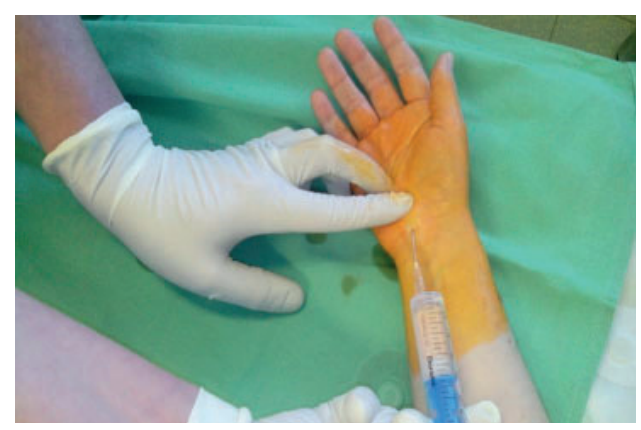

2. ábra

Paralel infiltráció

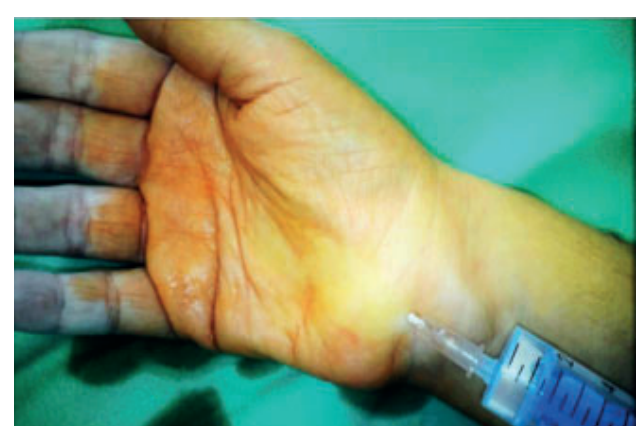

3. ábra

A „blanching"effektus 


\section{AZ INJEKCIÓZÁS TÍPUSAI}

\section{Klasszikus WALANT érzéstelenítés:}

Lidocain/adrenalin injekció beadása a közvetlenül operált terület érzéstelenítésére és vértelenítéséhez. Extravascularis Bier block elven múködik, lényege, hogy az operált terület (+ $1 \mathrm{~cm}$-es körzete) érzéstelen és vértelen.

\section{Digitális blokád, SIMPLE block:}

Kézujjakon végezhető DIP, PIP mútéteken, itt a lényeg, hogy az Oberst féle érzéstelenítéshez képest egy szúrással elérhető a kívánt érzéstelenség. SIMPLE blokád (mozaikszó: Single Injection in the Middle of the Proximal phalanx with Lidocaine and Epinehrine) esetén a palmáris oldalon a középvonalban az alapízületi barázdába egy injekció (2-3 ml) adásával elérhető a sugár érzéstelenítése anélkül, hogy az oldatot közvetlenül a digitális idegekhez adnánk (4. ábra). Figyelmet érdemel, hogy ez az érzéstelenítés a végpercen középpercen nem ér el megfelelő vértelenséget, így ki szoktuk egészíteni Salem-féle (levágott gumikesztyü ujjal kipólyázó) vértelenítési technikával.

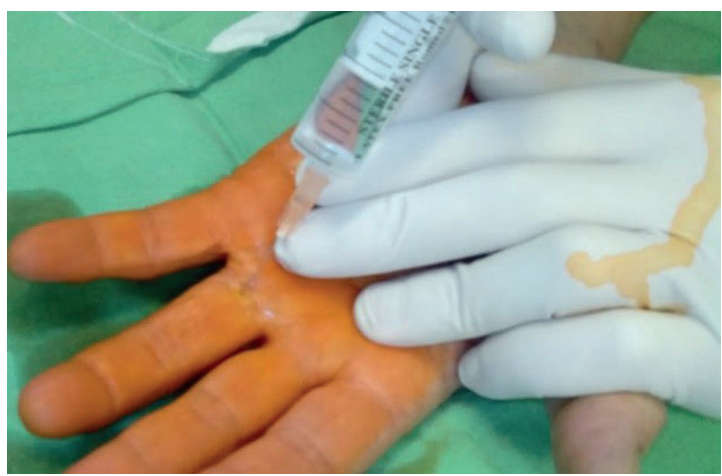

4. ábra

SIMPLE blokád

\section{Miért minimál invazív érzéstelenítési technika a WALANT módszer?}

A magyarázatot a Il. táblázat mutatja. Csökkenti a perioperatív terhelést a mútét előtti kivizsgálás szúkítése. A mútét napján különösebb teendő nincs, a páciens táplálkozhat, szokásos gyógyszereit be kell vennie. Nincs külön korlátozó előírás a mútét előtt. Közvetlenül a mútét körül a szabad mozgás, táplálkozás lehetősége adott. Nem használunk infúziót, nincs ágyhoz kötöttség. Maga az érzéstelenítés minimális fájdalommal jár. Mútét utáni időszakban a megfigyelési idő (paraméterek ellenőrzése, kötésellenőrzés) után a páciens hazabocsátható. Külön fontos hangsúlyozni, hogy a minimál invazivitás az érzéstelenítési módra és előkészítésre vonatkozik, és nem a mútét kivitelére. Mútétnél minden feltárás, a beavatkozás kiterjedése azonos az általános érzéstelenítésben végzett mútéti eljárással. 
II. táblázat Perioperatív összehasonlító táblázat aneszteziológust igénylő beavatkozás és WALANT esetén $(7,10)$

\begin{tabular}{|c|c|c|}
\hline Módszer / szempont & Narcosis, plexus, IVRA & WALANT \\
\hline Kivizsgálás & $\begin{array}{c}\text { Kötelező labor, } 40 \text { év felett } \\
\text { EKG, sz.e. légzésfunkció, } \\
\text { mellkas röntgen, altató orvosi } \\
\text { vizsgálatok }\end{array}$ & $\begin{array}{l}\text { Kivizsgálás nem szükséges, } \\
\text { kivétel anticoagulált beteg } \\
\text { laborvizsgálata, sz.e. EKG. }\end{array}$ \\
\hline $\begin{array}{c}\text { Kórházi megjelenések mútét } \\
\text { előtt }\end{array}$ & $\begin{array}{l}\text { A műtéti előtti kivizsgálásnak } \\
\text { megfelelően 2-5 alkalom. }\end{array}$ & Mútét napján \\
\hline Carentia & Mútét előtt 4-5 óra carentia & $\begin{array}{l}\text { Nincs, a betegeket bíztatjuk } \\
\text { reggeli fogyasztására }\end{array}$ \\
\hline Gyógyszerelés & $\begin{array}{l}\text { Altatóorvos által előírt } \\
\text { gyógyszerelés }\end{array}$ & $\begin{array}{c}\text { Szokásos napi reggeli gyógy- } \\
\text { szerelés }\end{array}$ \\
\hline Praemedicatio & $\begin{array}{c}\text { Altatóorvos által előírt } \\
\text { gyógyszerek }\end{array}$ & $\begin{array}{c}\text { Nem szükséges. Kizárólag } \\
\text { nagyon anxiosus páciensnél } \\
\text { anxiolitikum }\end{array}$ \\
\hline Infúzió & $\begin{array}{l}\text { Branül, infúzió bekötése, } \\
\text { ezzel járó fájdalom, ágyhoz } \\
\text { kötöttség }\end{array}$ & $\begin{array}{c}\text { Nincs infúzió, mútét előtt és } \\
\text { után szabad mozgás }\end{array}$ \\
\hline Mútét & $\begin{array}{c}\text { Altatószerek, sz.e. ébredést } \\
\text { segítő szerek, altatási mellék- } \\
\text { hatások kezelése }\end{array}$ & Lidocain/ Adrenalin injekció \\
\hline Ébredési szakasz & $\begin{array}{l}\text { Átmeneti tenebrosus állapot, } \\
\text { mellékhatások, ágyhoz kötött- } \\
\text { ség, posztoperatív fokozott } \\
\text { megfigyelés szükséges }\end{array}$ & $\begin{array}{c}\text { Mútét után teljes éberség } \\
\text { mozgási táplálkozási szabad- } \\
\text { sággal }\end{array}$ \\
\hline Hazabocsátás & $\begin{array}{c}\text { Ébredés után minimum } 5 \\
\text { órával panaszmentesség } \\
\text { esetén }\end{array}$ & $\begin{array}{c}\text { A dokumentáció elkészülése } \\
\text { után azonnal }\end{array}$ \\
\hline $\begin{array}{c}\text { Perioperatív } \\
\text { fájdalomcsillapítás }\end{array}$ & Narkózis után gyakran azonnal & A blokád hatása több órás. \\
\hline
\end{tabular}

\section{A páciens kiválasztása WALANT érzéstelenítésre}

A páciensek kiválasztása a WALANT érzéstelenítésben végzendő mútétekre négy lépésben zajlik.

1. Megfelelően kivizsgált betegen milyen mútéti indikáció áll fenn. A kiválasztott mútét saját tudásunk és tapasztalatunk alapján elvégezhető-e WALANT érzéstelenítéssel?
2. A páciens alkalmas-e WALANT érzéstelenítésre (fóbiák, életkor, kontraindikációk?)

3. Az érzéstelenítés részletes ismertetése után kéri-e ezt az érzéstelenítést, vagy elutasítja?

4. Szükséges-e kísérő betegségek, gyógyszerszedés esetén előzetes kivizsgálás, ha igen, ezeket előírjuk, gyógyszer beállítást megbeszéljük. 


\section{A WALANT érzéstelenítés kontraindikációs területei}

Nyilván vannak WALANT érzéstelenítésre alkalmatlan páciensek. Kisgyermekkorban, mentális zavarok esetén, erős túfóbiás betegeken, erősen ideges betegeken, illetve általában a kooperáció megfelelő hiánya esetén ez az érzéstelenítési módszer nem alkalmazható, még az érzéstelenítés kivihető, de a mútét alatti nyugalom, a kéz mozdulatlansága nem biztosított. Ha a páciens a megfelelő tájékoztatás után elutasítja ezt a módszert, nem alkalmazható.

A mútét maga alkalmatlan WALANT érzéstelenítésre. Ide tartoznak a nagyobb csont-ízületi mútétek, például csukló arthrodesis, carpectomia stb. Megjegyzem, WALANT érzéstelenítéssel végzett nyeregízületi arthroplasticáról, distalis orsócsont törés lemezes osteosynthesiséről már beszámoltak $(5,12)$.

Érdekes kérdés a laedált keringésű végtagokon végzett mútét. Találkoztunk praxisunkban néhány alkalommal elektrofiziológiai vizsgálattal bizonyított erős panaszokat okozó csukló alagút szindrómával dializált, Cimino shuntös betegekkel is. Itt a mandzsettás vértelenség kifejezetten ellenjavallt, a mútéteket WALANT érzéstelenítéssel el tudtuk végezni posztoperatív keringészavar vagy általános reakciók nélkül. Nincs tapasztalatunk Raynaud szindrómás betegek, vagy megelőzően érsérült betegek mútéteirôl. A WALANT egyik ritka kontraindikációjának a Raynaud fenomént, illetve az érsérülés utáni állapotokat tartjuk.

Szeptikus kézsebészeti mútéteknél a végperc folyamatok alapperc magasságú érzéstelenítéssel operálhatók. Helyi infiltráció egyéb esetekben a bakteriális propagáció esélye miatt elvetendő.

Ismeretlen viselkedésú, vagy malignitásra gyanús tumoroknál a helyzet hasonló. A tumorsejtek tovaterjedése lokális infiltráció esetén fokozott lehet, a tumorhoz vezető erek koagulációja nehézségekhez vezethet.

\section{WALANT érzéstelenítés speciális indikációs területei}

Éber állapotban adott az intraoperatív mozgásvizsgálat lehetősége. Speciális indikációs területe a WALANT érzéstelenítésben végezhető mútéteknek az, hogy a teljesen éber, jól kooperáló páciens mútét közben aktív mozgásokat tud végezni. Egyértelmú a mútét alatti vizsgálat pattanó ujj mútét esetén. Azonban nagyobb mútétek: tendolysisek, íntranszpozíciók, (kívánt ínhossz beállítása), arthrodesisek esetén (tengely, rotációs eltérés, ízületi szög beállítása) is nagy segítség a mútét alatti aktív mozgásvizsgálat.

Idős életkor és rossz általános állapotú, súlyos kísérőbetegségben szenvedők, akiknél az általános anesztéziai eljárások kontraindikáltak (nagy az altatási rizikó) is operálhatók WALANT technikával, tekintettel a minimális mútéti terhelésre.

\section{SZERVEZÉS, KIVITELEZÉS, FELTÉTELEK}

\section{Mútéti elöjegyzés}

A betegek előjegyzése a kézsebészeti szakrendelésen történik. Itt a megfelelő diagnózis és mútéti terv felállítása után ismertetjük a tervezett érzéstelenítési módot. Ez a tájékoztatás írásban is megtörténik, erre a célra kérdőívet és beleegyező nyilatkozatot rendszeresítettünk, amelyben részletesen leírjuk a tervezett érzéstelenítési módot, ismertetjük a várható esetleges mellékhatásokat, azok kezelési lehetőségét, a megfelelő érzéstelenítéshez szükséges anamnézist kikérdezzük. Ismertetjük az érzéstelenítés előnyeit is: szabad táplálkozás, szokásos gyógyszerek, szabad perioperatív mozgás, végig éber állapot, infúzió hiánya. A kérdőív része a mútét előtti teendók ismertetése is: felhívjuk a figyelmet a reggeli megfelelő étkezésre, szokásos gyógyszereinek bevételére. Megjelenési idő a kórházban 7 és 8 óra között. A megfelelő mútétről írásos tájékoztatást adunk, amely tartalmazza a diagnózist, a mútét leírását, és a várható szövődményeket is. Ezek megfelelő aláírása, mútéti beleegyezés szükséges. Eldöntjük, hogy a mútét elvégezhető-e egynapos sebészetben vagy hospitalizáció szükséges.

Amennyiben a páciens beleegyezik a WALANT érzéstelenítésbe a következő csoportokat állítjuk fel:

A/ Minden elökészítés, előzetes vizsgálat nélkül egynapos/ambuláns sebészetben ellátható 
B/ Egynapos/ambuláns sebészetben ellátható, de előkészítés vagy előzetes vizsgálat szükséges

Thrombocyta aggregáció gátló szedők: kis, 1-2 cm-es metszéssel végzett mútétek elvégezhetők a gyógyszer felfüggesztése nélkül. Nagyobb mútéti metszések esetén mútét előtt 5-7 nappal thrombocyta aggregáció gátló felfüggesztését, sz.e. LMWH szubsztitúciót rendelünk. Tartósan antikoagulált betegeknél (Syncumar, Marfarin) mútét előtt 3 nappal a gyógyszert leállítjuk, LMWH szubsztitúciót végzünk. Mútét napján reggel INR meghatározás szükséges. Tapasztalat alapján 3 napos felfüggesztés az INR-t normalizálja. Amennyiben az antikoaguláns visszaállítás orvosi menedzselését háziorvossal, belgyógyásszal biztosítjuk, egynapos sebészetben a kórkép ellátható, ellenkező esetben további hospitalizáció szükséges. Kis mútéti metszéssel járó mútéteknél az antikoaguláns kezelést nem állítjuk le, helyi vérzéscsillapitással, a kötés Spongostanos fedésével a posztoperatív vérzések minimalizálhatóak. Tartós szteroid szedés esetén szükséges a szteroid dózis preoperatív megemelése majd fokozatos csökkentése. Diabetes mellitus esetén lényeges eltérés nincs, beállított diabetológiai kezelés esetén a reggeli táplálkozás, megfelelő Inzulin vagy antidiabetikum használata kevésbé befolyásolja a diabetest, mint a narkózisban kivitelezett mútét a szükséges carentiával. Mútét előtt, valamint hazabocsátás előtt a vércukorszintet ellenőrizzük. Epilepsziás betegek esetén fontos a gyógyszer rendszeres szedése. Fokozott görcskészség miatt fokozott figyelem szükséges a vétlen intravascularis Lidocain beadás mellékhatásának elkerülésére. Gyakori rohamozóknál Seduxen adható. Májcirrózis, vérképzőszervi betegek, malignus betegségek fennállása esetén célszerű véralvadási faktorok mútét előtti meghatározása a várható vérzés megítélésére (vérkép, thrombocytaszám, INR). Súlyosabb szívbetegség esetén EKG vizsgálat elvégzését kérjük.

C/WALANT érzéstelenitésben végezhetö, de hospitalizációja szükséges

Tartósan antikoagulált beteg visszaállítása ambulanter nem megoldott. Tartós szteroid kezelt beteg perioperatív szteroid kezelése ambulanter nem megoldott. Bármely érzéstelenítéshez vagy műtéthez kötött szövődmény fellépése esetén a beteget hospitalizálni kell. Ha az egynapos/ambuláns ellátás szociális, közlekedési viszonyai hiányoznak: rossz szociális körülmények, nagy távolság, szállítás nem megoldott, telefonos elérés nem biztosított, szövődmény esetén közelben kórház vagy orvos nincs, a beavatkozás egynapos sebészetben nem engedélyezett (2).

\section{Kórházi megjelenés és teendők}

Kórházunkban egynapos sebészeti részleg múködik, úgynevezett „self contained unit” rendszerben, azaz az egynapos ellátásban részesülők külön részlegen kerülnek elhelyezésre, a mútétek során a teljes kórházi infrastruktúra - mútő, műszerek varróanyagok - adott. Súlyos szövődmény esetén aneszteziológiai és intenzív háttér is rendelkezésre áll. Kórházi felvétel után általában az egynapos sebészeti részlegen történik a betegek elhelyezése és előkészítése.

\section{Mütő elökészítő}

Kórházunkban a tervezett WALANT érzéstelenítéssel végezhető mútétekre hétfői napon kaptunk mútői időt. A mútéteket a központi mútőben végezzük, itt a műszerelés, röntgen képerősítő, koagulátor, teljes műszer és varróanyag készlet, nagyítási lehetőség adott. Mútéti sorozatokat végzünk, általában a mútéti szám 6-10 mútét. A betegeket betegszállítók viszik a központi mútőbe, a zsiliprendszer figyelembevételével átöltöztetve (kórházi papír mútőruhában, maszkban, sapkában). A műtő traktusban külön kézsebészeti előkészítő múködik, itt történik a betegek érzéstelenítése, megfigyelése mútét előtt. Az előkészítőben előre elkészített steril, csomagolt tálcákkal dolgozunk, mely betegenként tartalmazza a steril kötszereket és izolálókat, a szúrás előtti lemosáshoz szükséges eszközöket és anyagokat.

Elökészítő tálca érzéstelenítéshez: $2 \mathrm{db}$ steril compress; egyszer használatos múanyag fogó lemosáshoz, tupferek; 5, 10, illetve 20 $\mathrm{ml}$ fecskendő; tű az érzéstelenítő oldat felszívásához, 25 gauge-os tû a beadáshoz. Steril lapok az érzéstelenített terület fedésére, steril múanyag pohár a lemosó oldat tárolásához. Egyéb anyagok: lidocain/adrenalin injekció, lemosó, 8,4\%-os bikarbonát oldat, fiziológiás só hígításhoz, steril gumikesztyúk.

$\mathrm{Az}$ érzéstelenítendő területet szokásos 
sebészi fertőtlenítéssel mossuk le. Elvégezzük az érzéstelenítést, a szúrás helyét steril lappal fedjük, a végtagot steril compressbe csomagoljuk, így visszük műtőbe. A műtő előkészítő 3 ágyas. Egyszerre az első három beteg kerül ide, itt megtörténik az érzéstelenítésük, majd 30 perc eltelte után kezdődik az első mútét. $A z$ első mútét elvégzése után már az előkészítőben van a 4 . beteg, a két mútét között elvégezzük az érzéstelenítését, és így tovább. Ezzel a módszerrel a mútő lefoglaltságának egy mútétre eső ideje jelentősen csökken, gyakorlatilag a WALANT érzéstelenítésben végzett mútéteknél 90 perces mútő időben $5-7$ mútét végezhető el. Kiesik az altatási, ébredési szak, a lassú betegcsere okozta mútői idő. Perioperatív megfigyelőlapot vezetünk: vérnyomás, pulzus, oxigén szaturáció, mútét kezdete és vége, alkalmazott gyógyszerek, szükséges kötözés regisztrációja a kórházban tartózkodás alatt.

\section{Posztoperativ teendők}

Mútőből a pácienst ülőkocsival az egynapos sebészeti részlegre szállítják vissza. Itt pihenhet, táplálkozhat, mozoghat tetszése és igényei szerint. Osztályon megtörténik a kötésellenőrzés (utóvérzés, szoros kötés) az általános állapot ismételt ellenőrzése (perioperativ adatlap további vezetése) szükség esetén gyógyszerek adása stb. A kimeneteli ellenőrzés és dokumentáció elkészülése után a pácienst hazabocsátjuk.

\section{EREDMÉNYEK}

Kórházunkban a tervezett kézsebészeti mútétek nagy részét egynapos sebészet keretein belül végezzük. A kézsebészeti mútétek körülbelül $80 \%$-a volna elvégezhető egynapos ellátásban (2). A kézmútétek jelentős része alkalmas erre az ellátási formára. A jelenleginél több mútét lenne végezhető, ha a finanszírozás rugalmasabb lenne. Sajnos a finanszírozás beosztásai több sebből véreznek. Aki operál, tudja, hogy a várható szövődmények a mútét elvégzésének pontosságától és nem a hospitalizáció idejétől függenek, azaz a várható szövődmény már a műtét alatt eldől. Másfelől ugyanolyan műtéti előkészítést, anyagszükségletet, várható szövődményarányt mutató kézmútétek egy része végezhető egynapos ellátásban, máskor 2-3 napos hospitalizációt írnak elő a szabályok. Ezek újra gondolása szükséges volna.

Feldolgoztuk a WALANT bevezetése előtti 2013. év, valamint a WALANT betanulási ideje utáni 2017. év kézsebészeti egynapos ellátási adatait érzéstelenítési szempontból (5-6. ábrák).

Látható, hogy a WALANT érzéstelenítéssel nagyszámú korábbi altatást váltottunk ki. Jelenleg a tervezett egynapos kézsebészetben csak az esetek harmadában vesszük igénybe altatóorvos közremúködését. Korábban helyi érzéstelenítésben végeztük a pattanó ujj ínhüvelybemetszéseit, néhány DIP ízületi beavatkozást (pl. tenodermodesis, extenzor reinzerció). A WALANT bevezetésével a repertoár kibővült, de Quervain tenosynovitisek, egy sugaras Dupuytren betegség aponeurectomiái, aponeurotomiák, epicondylitisek részleges izomeredés leválasztásai, ganglionok, biztosan jóindulatú lágyrésztumorok, csukló alagút szindróma mútétei, DIP, PIP desisek, tendolysisek, kisebb bőrpótlások átkerültek ebbe az érzéstelenítési kategóriába. A technikát folyamatosan tanuljuk, fejlesztjük, tervezzük íntranszpozíciók, primer ínvarratok érzéstelenítésének bevezetésére.

Külön kérdéskör az ügyeleti sérülések ellátása. Fedett, vagy minimális feltárást igénylő ujjperc, kézközépcsont törések műtétei, egyes ínsérülések, sebellátások elvégezhetőek WALANT érzéstelenítésben, mellette szól, hogy az ellátáshoz nem szükséges többórás várakozás (carentia), nem szükséges nagyobb kivizsgálás. Néhány sérülést így úgynevezett sürgősségi egynapos sebészetben lehetséges ellátni. Ellene szól, hogy az ügyeleti ellátásban olykor nehezebb a szervezés, nincs ügyeletben külön betegelőkészítő az érzéstelenítéshez, nincs külön megfigyelő személyzet. Emiatt az ügyeleti ellátásban az elvégezhető mútétek érzéstelenítési aránya még mindig az altatások dominanciáját mutatja. 

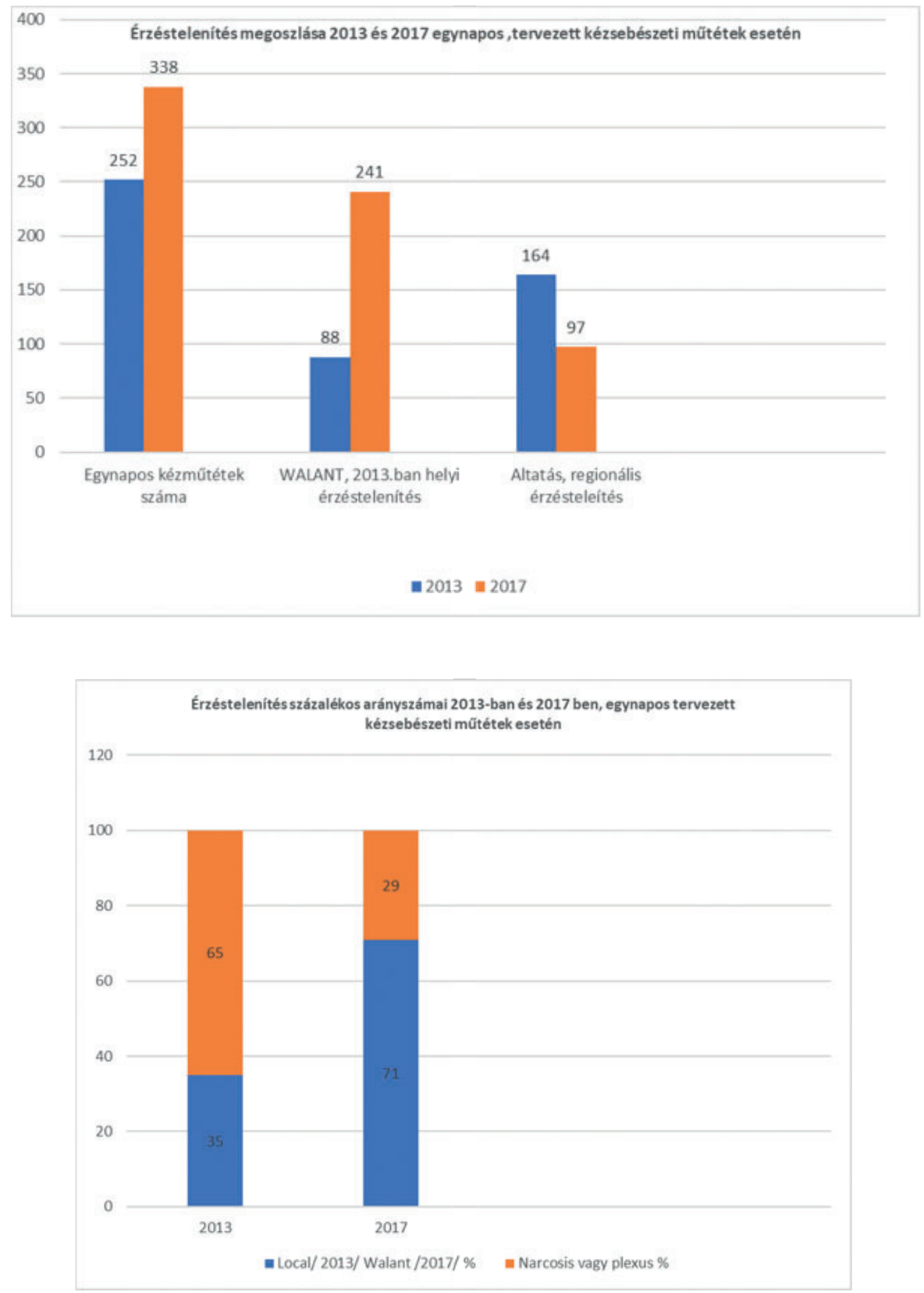

5-6. ábrák

Kézsebészeti egynapos ellátás adatai érzéstelenités szempontjából 


\section{Financiális megfontolások}

Közlésre kerültek már a WALANT módszerrel végzett mútétek során elérhető financiális előnyökről szóló dolgozatok. Észak-Amerikában ezeket a mútéteket gyakran nem kórházi mútőben, hanem úgynevezett office (rendelő) rendszerben is végzik (14).

A költségmegtakarítás egyfelől az egynapos sebészeti formából ered (nincs hotelköltség), másfelől az érzéstelenítés és előkészítés egyszerű voltából adódik. WALANT érzéstelenítésnél általában kiesik a premedikáció, az elhúzódó érzéstelenítés miatt ritkán van szükség posztoperatív kórházi fájdalomcsillapításra. A narkózisban végzett mútétek esetén a perioperatív infúziók, premedikáció, altatószer kézsebészeti mútétenként 6-7000 Ft-ba kerülnek. Ezzel szemben a WALANT érzéstelenítéshez használt $10 \mathrm{ml}$ 2\%-os Lidocain/Adrenalin injekció ára 164,- Ft. A költségmegtakarításhoz szükséges még hozzászámolni egyfelől a kieső altatóorvosi és asszisztensi munkát, az altatógép használatát, valamint azt, hogy a műtői idő kihasználtsága lényegesen jobb a WALANT mútéti sorozatnál, mint az altatásos mútétek esetén. Átlagosan 5-7 mútét WALANT érzéstelenítésben megfelelő szervezés esetén 1,5-2 óra alatt lezajlik. Altatás esetén 2,5-3,5 órával kell számolnunk.

\section{MEGBESZÉLÉS}

A WALANT érzéstelenítés tanulandó eljárás. Alkalmazásához türelem, gyakorlat szükséges. Mivel az így elérhető vértelenség nem azonos a kipólyázásos vértelenség során megszokottal (rózsaszín vértelenség), a mútéti megváltozott látási viszonyokat tanulni kell. A WALANT érzéstelenítést inkább a nagyobb gyakorlattal rendelkezők figyelmébe ajánljuk, akik ezeket a mútéteket már nagy számban végezték kipólyázásos vértelenséggel, és biztos helyi sebészeti anatómiai, mútéttechnikai ismeretek birtokában vannak.

A rózsaszín vértelenség során a bemetszésekkor főként a subcutan zsírszövetben számos apró vérzést találunk, amelyek a kipólyázásos vértelenség esetén nem is láthatóak. Ezeket koagulátorral csillapítjuk. Megfelelő vérzéscsillapítás esetén később a mútéti területben zavaró vérzést nem észlelünk, talán a nagyobb számú koaguláció miatt műtét végén jelentős lényeges vérzés sem látható. A kipreparált képletek a megmaradó vérellátásuk miatt természetes színúek, ezt is szokni kell (7. ábra).

Fontosnak tartjuk az érzéstelenítés precíz kivitelezését, a Lalonde-szabályok pontos betartását. Sietséggel, vagy nem kellő figyelemmel végzett érzéstelenítés felesleges fájdalmakat, vagy a mútéti terület részleges érzéstelenítését vonhatja maga után. Fontos az érzéstelenítés és mútét közötti előírt időintervallum betartása. Irodalmi adatok 25 percet javasolnak, mi 30 perccel az érzéstelenítés után kezdjük a mútétet. Ez idő alatt az érzéstelenítő és lokális vértelenítő hatás optimális mértéket ér el. A beadott oldat eloszlik, az operált területen már nem találunk „vizes, felfújt" területeket. Mútétek végén az esetlegesen még látható vérzéseket koaguláljuk. A vérzéscsillapítás effektusa tovább növelhető, ha nagyítás mellett dolgozunk. Mivel kipólyázás nincs, minden vérzést kontrollálni lehet (8. ábra). Emiatt egy idő után kisebb mútétek után elhagytuk a drenálást, valamint a posztoperatív szoros kompressziós kötés felhelyezését is. Műtét végén enyhe kompreszsziós kötést helyezünk fel, amelyben a beteget hazabocsátjuk. Bár esetszámunk még kicsi, elmondhatjuk, hogy posztoperatív vérzéssel alig találkoztunk (utóvérzés nem volt, seb alatti haematomát két esetben észleltünk). Sebgyógyulási zavar öt esetben fordult elő, ebből két esetben sebfertőzés, két esetben varratszedés utáni trauma okozta a mútéti sebek szétválását. Érzéstelenítés során a leírt lidocain/adrenalin szövődmények alig észlelhetők. Néhány esetben múló tremor, kollaptiform rosszullét, anxiozitás előfordult. Nem észleltünk epilepsziás rohamot, allergiás reakciót, kardiológiai szövődményt sem. Az átmeneti rosszullétek gyógyszeres beavatkozás nélkül néhány perc alatt rendeződtek. Posztoperatív lokális keringészavart egyetlen esetben sem láttunk.

Mútét utáni fájdalom miatt a kórházi tartózkodás alatt lényeges gyógyszeradás nem volt szükséges. Általában az érzéstelenítés 5-6 órán át fennáll, otthon egyszerü per os analgetikummal csillapítható fájdalmakról számoltak be a betegek. Összességében elmondhatjuk, hogy a kellő gyakorlat megszerzése után egy, a páciensek perioperatív terhelését 
jelentősen minimalizáló páciens barát eljárás a WALANT érzéstelenítésben végzett mútét. A mútétek költségeit jelentősen csökkentő módszer. Mi ennek a metódusnak tanulási fázisában vagyunk. A mútéti repertoárt fokozatosan bővítjük. Nagy lehetőségeket látunk az intraoperatív aktív mozgásvizsgálat adottsága miatt ínmútétek végzésére, egyes akut kézsérülések ellátására.

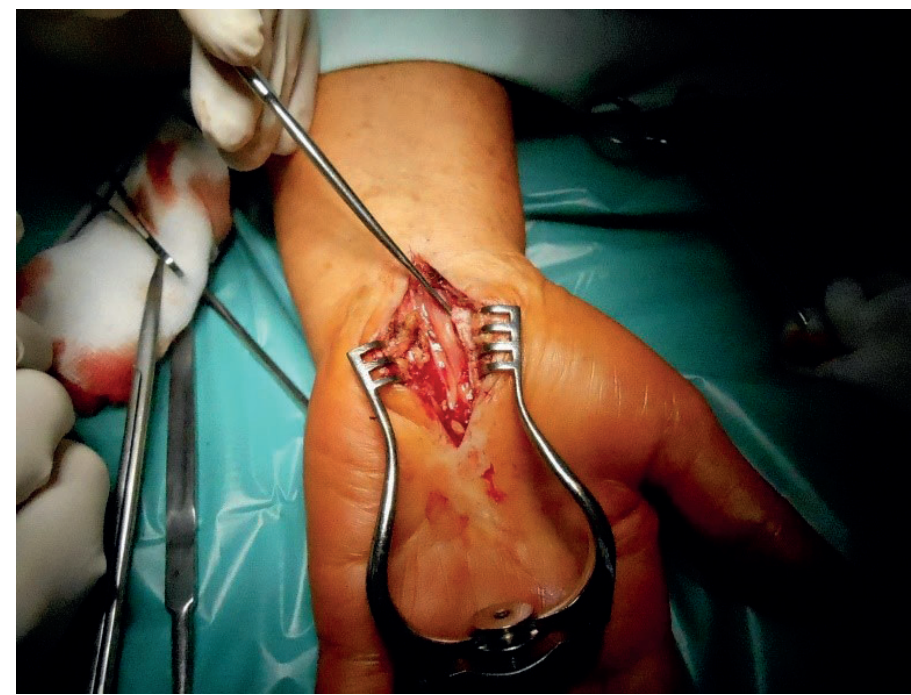

7. ábra

Carpal tunnel felszabadítás, WALANT érzéstelenítésben

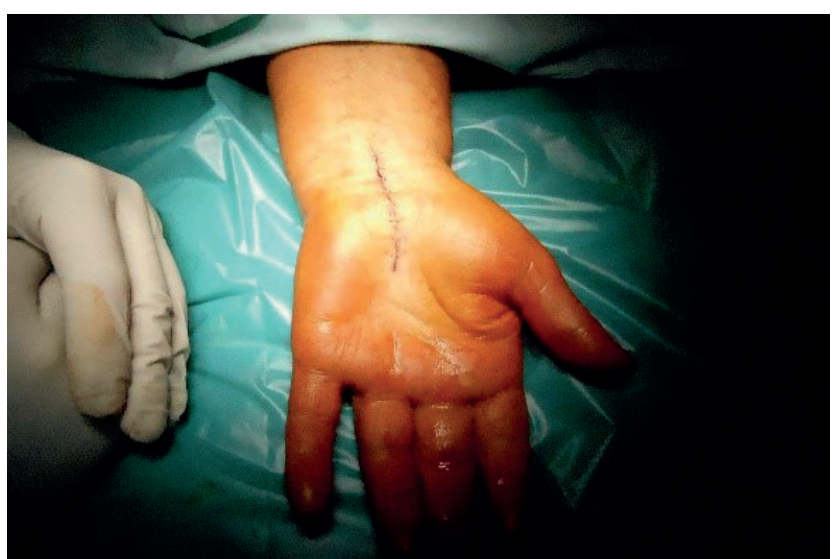

8. ábra

Sebzárás WALANT érzéstelenitésnél, vérzés nem látható 


\section{IRODALOM}

1. Chowdhry S., Seidenstricker L., Cooney D. S., Hazani R., Wilhelmi B. J.: Do not use epinephrine in digital blocks: myth or truth? Part II. A retrospective review of 1111 cases. Plast. Reconstr. Surg. 2010. 126. (6): $2031-2034$. https://doi.org/10.1097/prs.0b013e3181f44486

2. Gaál Cs.: Sebészet. Budapest, Medicina. 2012. 1930-1943. p.

3. Gunasagaran J., Sean E. S., Shivdas S., Amir S. T., Ahmad T. S.: Perceived comfort during minor handsurgeries with wide awake local anaesthesia no tourniquet (WALANT) versus local anaesthesia (LA)/tourniquet. J. Orthop. Surg. 2017. 25. (3): 1-4. https://doi.org/10.1177/2309499017739499

4. Hagert E., Lalonde D.: Time to bury the adrenaline-myth! Safe use of adrenaline anesthesia in hand surgery and orthopedics. Lakartidningen. 2015. 112: C4MC

5. Huang Y. C., Hsu C. J., Renn J. H., Lin K. C., Yang S. W., Tarng Y. W., Chang W. N., Chen C. Y.: WALANT for distal radius fracture: open reduction with plating fixation via wideawake local anesthesia with no tourniquet. J. Orthop. Surg. Res. 2018. 13. (1): 195. https://doi.org/10.1186/s13018-018-0903-1

6. Lalonde D.: Minimally invasive anaesthesia in wide awake hand surgery. Hand Clin. 2014. 30: (1): 1-6. https://doi.org/10.1016/i.hcl.2013.08.015

7. Lalonde D., Martin A.: Tumescent local anesthesia for hand surgery: improved results, cost effectiveness, and wide-awake patient satisfaction. Arch Plast Surg. 2014. 41. (4): 312-316. https://doi.org/10.5999/aps.2014.41.4.312

8. Lalonde D. H., Wong A.: Dosage of local anaesthesia in wide awake hand surgery. J. Hand Surg. Am. 2013. 38. (10): 20252028. https://doi.org/10.1016/j.jhsa.2013.07.017

9. Lalonde D., Martin A.: Epinephrine in local anaesthesia in finger and hand surgery: The case for wide awake anaesthesia. J. Am. Acad. Orthop. Surg. 2013. 21. (8): 443-447.

10. Lalonde D.: Wide awake hand surgery. Stuttgart. Thieme. 2015. 287 p. ISBN-978-1626236622

11. Lalonde D., Eaton Ch., Amadio P. C., Jupiter J. B.: Wide-awake hand and wrist surgery: A new horizon in outpatient surgery. Instr. Course Lect. 2015. 64. 249-259.

12. Müller C., Christen T., Heidekruger P., Lamouille J., Raffoul W., McKee D., Lalonde D. H., Durand S.: Wide-awake anesthesia no tourniquet trapeziometacarpal joint prosthesis implantation. Plast. Reconstr. Surg. Glob. Open. 2018. 6. (4): e1714. https://doi.org/10.1097/gox.0000000000001714

13. Pires Neto P. J., Moreira L. A., Las Casas P. P.: Is it safe to use local anesthesia with adrenaline in hand surgery? WALANT technique. Rev. Bras. Ortop 2017. 52. (4): 383-338. https://doi.org/10.1016/i.rboe.2017.05.006

14. Rhee P. C., Fischer M. M., Rhee L. S., McMillan H., Johnson A. E.: Cost savings and patient experiences of a clinic-based, wide-awake hand surgery program at a military medical center: A critical analysis of the first 100 procedures. J. Hand Surg. Am. 2017. 42. (3): 139-147. https://doi.org/10.1016/i.jhsa.2016.11.019

15. Teo I., Lam W., Muthayya P., Steele K., Alexander S., Miller G... Patients' perspective of wide-awake hand surgery--100 consecutive cases. J. Hand Surg. Eur. 2013. 38. (9): 992-999. https://doi.org/10.1177/1753193412475241

\section{Dr. Sasvári Edgár}

8400 Ajka, Pálma u. 67.

E-mail: sasvariedgar@gmail.com 